\title{
Toll-like receptor 2 and 4 expression in the bovine corpus luteum during the different stages of the estrous cycle
}

\author{
Mehmet Osman Atlii ${ }^{1,5}$, Mehmet Köse', Mehmet Salih Kaya², Nurettin Aydilek², Aydin Güzeloğlu ${ }^{3}$, \\ Milo C. Wiltbank ${ }^{4}$ \\ ${ }^{1}$ Department of Obstetrics and Gynaecology, Faculty of Veterinary Medicine, Dicle University, Diyarbakır, Turkey. \\ ${ }^{2}$ Department of Physiology, Faculty of Veterinary Medicine, Dicle University, Diyarbakır, Turkey. \\ ${ }^{3}$ Department of Genetics, Faculty of Veterinary Medicine, Selcuk University, Konya, Turkey. \\ ${ }^{4}$ Endocrinology-Reproductive Physiology Program and Department of Dairy Science, University of Wisconsin, Madison,
} Wisconsin USA.

\begin{abstract}
The aim of this study was to elucidate the presence of components of the innate immune system in the bovine corpus luteum (CL) by detecting the expression and cell-specific localization of TLR2 and TLR4 during different stages of the estrous cycle in a control study design. Bovine CL samples were collected from a local slaughterhouse and assigned to three groups as follows: developing $\mathrm{CL}$ (dCL; $\mathrm{n}=6$, approx. days 3-6), mature $\mathrm{CL}(\mathrm{mCL} ; \mathrm{n}=5$, approx. days 8-12), and regressing $\mathrm{CL}(\mathrm{rCL} ; \mathrm{n}=5$, approx. days 17-19). An upregulation of TLR2 mRNA was detected only in rCL $(\mathrm{P}<0.05)$. Localization of the TLR2 protein was particularly apparent in luteal cells and a prominent immunofluorescent signal corresponding to TLR2 was detected only in rCL. TLR4 mRNA were higher in mCL and $\mathrm{rCL}$ compared to dCL $(\mathrm{P}<0.05)$. The presence of the TLR4 protein in bovine CL was clearly detected in the luteal cells of both mCL and rCL. The results of this study suggest a role for TLRs in the development, maintenance, and regression of bovine CL. TLR signaling mediated pathway in luteal cells may involve in the regression of CL via regulation of TLR2 and TLR4.
\end{abstract}

Key words: bovine, corpus luteum, toll-like receptors.

\section{Introduction}

The corpus luteum (CL) forms after ovulation from remaining Graafian follicular cells and secretes progesterone, which has vital functions for the establishment and maintenance of pregnancy in many species, including cows. If a pregnancy does not occur, the $\mathrm{CL}$ is required to regress in order to allow the cow to return to estrus. Prostaglandin $\mathrm{F}_{2 \alpha}\left(\mathrm{PGF}_{2 \alpha}\right)$, released by the non-pregnant uterus, initiates regression of the $\mathrm{CL}$ in the cows (Pate et al., 2012). The CL is composed of multiple cell types, including steroidogenic (large luteal cells and small luteal cells) and non-steroidogenic cells (endothelial cells, pericytes, fibrocytes and immune cells; Wiltbank 1994) and this mixture of cells altogether contribute to the formation and demise of the CL. For example, despite the fact that the $\mathrm{PGF}_{2 \alpha}$ receptor was only detected in large luteal cells where the first luteolytic signal was expected to start (Mamluk et al., 1998), our previous studies have shown that luteolytic induction occurs in endothelial cells earlier than in luteal cells (Atli et al., 2011; Atli et al., 2012). Although the role of immune cells in the CL was previously thought to be in phagocytosis following luteolysis (reviewed by Pate and Landis Keyes, 2001), the immune cell population and chemokines in the CL are affected during functional luteolysis in the early response to $\mathrm{PGF}_{2 \alpha}$ (Shirasuna et al., 2012). Moreover, immune system roles were demonstrated in the $\mathrm{dCL}$ in a previous study (Poole and Pate 2012). These results indicate that both the development and regression of the $\mathrm{CL}$ are regulated by complex mechanisms.

Toll-like receptors (TLRs), as transmembrane proteins, are an important part of the innate immune system and play roles in the activation of the acquired immune system (Akira, 2003). In addition to their roles in pathogen recognition, TLRs interact with secreted or released endogenous molecules such as reactive oxygen species (ROS), heat shock proteins, and proteins released from dying cells (see review by Piccinini and Midwood 2010). Therefore, activation of TLRs can induce both physiological and pathological processes, including pro/anti-inflammatory processes (Kannaki et al., 2011). In the reproductive system, TLRs participate in ovulation, fertilization, placental function, trophoblast invasion, parturition, and protection of the reproductive tract from pathogens (Horne et al., 2008; Kannaki et al., 2011; Koga and Mor 2008; Silva et al., 2010). They also allow communication between many other components of the immune system (Koga and Mor 2008). TLRs are generally expressed by different types of immune cells, but their expression is also detected in cells of reproductive tissues, such as granulosa cells, endometrial luminal and stromal cells, trophoblasts, and cervical cells (Horne et al., 2008; Koga and Mor 2008). In bovine endometrium, TLRs play roles in the prevention of endometrial infection with microorganisms as they are expressed on epithelial cells of the endometrium (Davies et al., 2008). When TLR signaling is induced by appropriate signal molecules, many downstream targets of TLRs, including IL4, IL8, COX2, and TNF $\alpha$, are regulated (Horne et al. 2008; Silva et al. 2010). Since the expression of many pro/anti-inflammatory molecules is affected during formation and regression of the CL (Skarzynski and Okuda 2010), the expression of TLRs may play critical roles in regulating the changing physiology of the CL. TLR2 and TLR4 are the best characterized TLRs regarding their signaling mechanisms and are mediated by many inflammatory pathways and endogenous 
substances. Recently, in the CL, the expression of TLR2 and TLR4 was predominantly localized to luteal cells and blood vessels and increased during the mid(Lüttgenau et al., 2016) and late luteal phase (Lüttgenau et al., 2016; Gadsby et al., 2017). Therefore, the aims of the present study were to approve the recent findings on 1) the expression of TLR2 and TLR4 during different stages of the estrous cycle, and 2) on cell-specific localization of TLR2 and TLR4 in the bovine CL.

\section{Materials and Methods}

\section{CL tissue collection}

Bovine CL samples were collected from a local slaughterhouse in Konya, Turkey. Genital tracts, including ovaries, were obtained within 10 minutes after slaughter and immediately transferred to the laboratory on ice. Genital tracts were washed with PBS and classified based on the criteria mentioned by Arosh et al. (2002) that characterized the stage of the estrous cycle through morphology of the ovarium and uterus. A further classification for the collected bovine CLs was carried out by examining the expression of StAR mRNA and protein. The CLs were removed and assigned to three groups as follows: developing $\mathrm{CL}(\mathrm{dCL} ; \mathrm{n}=6$, approx. days 3-6), mature $\mathrm{CL}$ (mCL; $\mathrm{n}=5$, approx. days 8-12), and regressing $\mathrm{CL}(\mathrm{rCL} ; \mathrm{n}=5$, approx. days 17-19). All animal material collection procedures were approved by the Ethics Committee of Dicle University, Diyarbakir, Turkey. The CLs were dissected, snap-frozen in liquid nitrogen, and stored at $-80^{\circ} \mathrm{C}$ for later isolation of RNA. A portion of $\mathrm{CL}$ tissue was fixed in a $4 \%$ paraformaldehyde solution overnight at $4^{\circ} \mathrm{C}$ and then dehydrated using serial dilutions of methanol $(25 \%, 50 \%$, $75 \%$, and $100 \%$ ). Samples were stored in methanol at $20^{\circ} \mathrm{C}$ until evaluated by immunofluorescence.

\section{$R N A$ isolation, $R T$ reaction, and Quantitative PCR}

About $20 \mathrm{mg}$ of CL tissue was homogenized in Trizol $^{\circledR}$ (Invitrogen, Carlsbad, CA, USA) using a homogenizer (Slientcruzer M, Heidolph, Germany). Total RNA was isolated according to the manufacturer's protocol. The RNA integrity was evaluated by agarose gel $(1.5 \%)$ electrophoresis and optical density measurements at $260 / 280 \mathrm{~nm}$ of $2 \pm 0.1$ with a NanoDrop ND-2000 (Thermo Scientific,Wilmington, DE, USA). Two micrograms of RNA were incubated with DNAse I (Fermentas Vilnius, Lithuania) to eliminate possible genomic DNA contamination and then the RNA was reverse transcribed in the presence of oligo-dT primers using the Revert Aid First Strand cDNA Synthesis Kit (Fermentas Vilnius, Lithuania) according to the manufacturer's protocol. To clarify RT specificity, analyses were also performed with all components of the RT kit without including RNA (RT negative). Oligonucleotide primers for StAR, TLR2, TLR4, and GAPDH were designed using Primer3 from the sequences in the NCBI gene database or from published primer sequences (Atli et al., 2012). The primer pair sequences and product sizes are shown in
Table 1. All PCR reactions were set up as follows: $5 \mu \mathrm{l}$ SYBR Green Master Mix (Maxima ${ }^{\mathrm{TM}}$ SYBR, 2X, Fermentas Vilnius, Lithuania), $2.5 \mathrm{pMol}$ of each primer, $0.5 \mu \mathrm{l} \mathrm{cDNA}$, and ddH2O to bring the final volume to $10 \mu \mathrm{L}$. Thermal cycling was performed by incubating the mixture at $50^{\circ} \mathrm{C}$ for $2 \mathrm{~min}$ with subsequent denaturation at $95^{\circ} \mathrm{C}$ for $10 \mathrm{~min}$. This was followed by 40 cycles of denaturation, annealing, and amplification $\left(95^{\circ} \mathrm{C} 30 \mathrm{sec}, 60^{\circ} \mathrm{C} 30 \mathrm{sec}, 72^{\circ} \mathrm{C} 30 \mathrm{sec}\right)$. All reactions were performed on an Applied Bioscience Stepone plus Real-Time PCR System (Foster City, CA, USA). Melting curve analyses were performed as follows: $95^{\circ} \mathrm{C}$ for $1 \mathrm{~min}$ followed by fluorescence measurements performed at $1.5^{\circ} \mathrm{C}$ increments between $60^{\circ} \mathrm{C}$ and $95^{\circ} \mathrm{C}$. In each run, negative controls without a cDNA template and RT negative controls were included. To verify reaction specificity, amplification products were evaluated by separation on agarose gel. All samples were evaluated in duplicate for each cDNA. From RNA extraction to real-time PCR, were performed twice as technical replicates. Amplifications were performed on a serial dilution of pooled cDNA to determine the primer efficiency. The qPCR amplification efficiency for specific gene amplicons was similar.

Table 1. List of primer used in real-time PCR.

\begin{tabular}{|c|c|c|}
\hline Genes & Primers & Size \\
\hline StAR & $\begin{array}{l}\text { F 5' - cagcagaagggtgtcatcaga-3' } \\
\text { R 5'- gagaggacetggttgatgatg }-3 \text {, }\end{array}$ & 152 \\
\hline TLR2 & $\begin{array}{l}\text { F 5'- ggttttaaggcagaatcgtttg }-3, \\
\text { R 5'- aaggcactgggttaaactgtgt }-3 \text {, }\end{array}$ & 190 \\
\hline TLR4 & $\begin{array}{l}\text { F 5'- tgctggctgcaaaaagtatg }-3^{\prime} \\
\text { R 5'- ccctgtagtgaaggcagagc }-3 \text {, }\end{array}$ & 149 \\
\hline GAPDH & $\begin{array}{l}\text { F 5'- aatatcatccetgcttctactgg }-3^{\prime} \\
\text { R 5'- catacttggcaggtttctcca }-3 \text { ' }\end{array}$ & 154 \\
\hline
\end{tabular}

\section{Immunofluorescence}

Tissue sections were deparaffinized in xylene, rehydrated, and boiled in $10 \mathrm{mM}$ sodium citrate $(\mathrm{pH}$ 6.0 ) for $20 \mathrm{~min}$. Tissues were washed with a solution containing Tris- $\mathrm{HCl}(25 \mathrm{mM}$ pH 7.5), $\mathrm{NaCl}(140 \mathrm{mM})$, $\mathrm{KCl}(2.7 \mathrm{mM})$, and $0.1 \%$ Tween-20 (TBSTw) and nonspecific binding sites were blocked for $1 \mathrm{hr}$ in a blocking solution (TBSTw containing 1\% Blocking Reagent (Roche Diagnostics, Indianapolis, IN), normal goat sera (for TLR4) or normal human serum (for TLR2), and $1 \%$ bovine serum albumin. Tissues were incubated overnight at $4{ }^{\circ} \mathrm{C}$ with primary antibodies diluted in the blocking solution as follows: 1:100 rabbit anti-StAR (sc-25806, Santa Cruz Biotech, polyclonal), 1:100 rabbit anti-TLR4 (AA 780-830, antibodiesonline.com, polyclonal), 1:150 human antiBovineTLR2 (CD282 Antibody, AbD Serotec, Bio Rad, USA, monoclonal). After several washes with TBSTw, tissues were incubated for $1 \mathrm{hr}$ with the blocking solution containing 1:250 Dylight488-conjugated goat anti-rabbit IgG (Jackson Immunoresearch, West Grove, PA) (for TLR4, StAR) and 1:250 mouse anti human: Fluorescein isothiocyanate (FITC, for TLR2, AbD Serotec, Bio Rad, USA). Auto fluorescence was also blocked by Autofluorescence Blocking Solution 
containing $10 \mathrm{mM} \mathrm{Cu(II)SO} 4$ and $50 \mathrm{mM}$ NH4Ac. For negative controls, sections were incubated by secondary antibodies or isotype control. Labeled tissue sections were counterstained with antifade mounting medium with DAPI (Vectashield, Vector Lab, USA). Fluorescence images were captured using a Nikon Eclipse E600 compound microscope (Nikon Instruments Inc., Melville, NY).

\section{Statistical analysis}

Glyceraldehyde-3 phosphate dehydrogenase (GAPDH) was used to normalize the expression of target genes. The use of GAPDH as a house-keeping gene has been previously validated (Atli et al., 2012). Furthermore, we also did validate the consistency of steady-state GAPDH concentrations in the different stages of CLs. Before statistical analysis, data normalization was performed with the necessary assumptions according to Livak and Schmittgen (2001) via the $2^{-\Delta \mathrm{Ct}}$ method. Non-parametric tests were applied. Comparisons between the different stages of the estrous cycle were carried out using Kruskal-Wallis tests and the Mann-Whitney U-test was applied post hoc. Data were considered statistically significant when $P$ values were lower than 0.05 .

\section{Results}

Expression of StAR $m R N A$ and protein in collected corpus luteum samples

An important component of progesterone production, StAR mRNA and protein expression were evaluated in collected corpus luteum samples. While expression of StAR mRNA was upregulated between $\mathrm{dCL}$ and $\mathrm{mCL}$, it was dramatically downregulated in rCL (Fig. 1). Moreover, protein localization of StAR in luteal cells also decreased to an undetectable level on microscopy observation in rCL (Fig. 2).

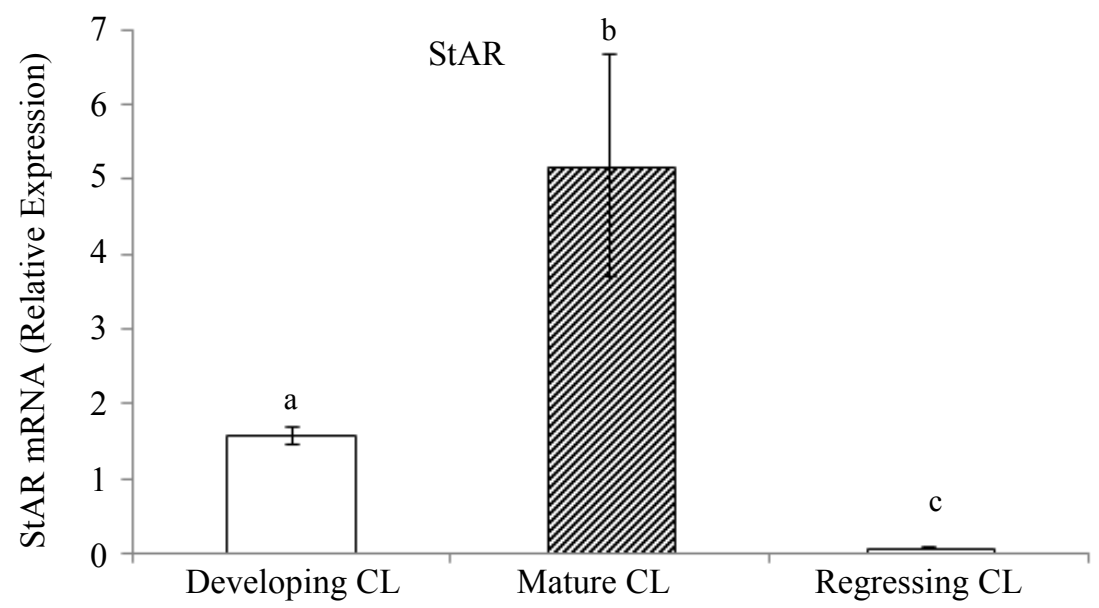

Figure 1. Relative expression of StAR mRNA (Mean \pm SEM) in the bovine CL during the different stages of the estrous cycle; developing CL (dCL; $n=6$, approx. days 3-6), mature $\mathrm{CL}(\mathrm{mCL} ; \mathrm{n}=5$, approx. days $8-12$ ), and regressing $\mathrm{CL}$ ( $\mathrm{rCL} ; \mathrm{n}=5$, approx. days $17-19)$ The different letter $(a, b, c)$ indicates differences $(\mathrm{P}<0.05)$ among groups.
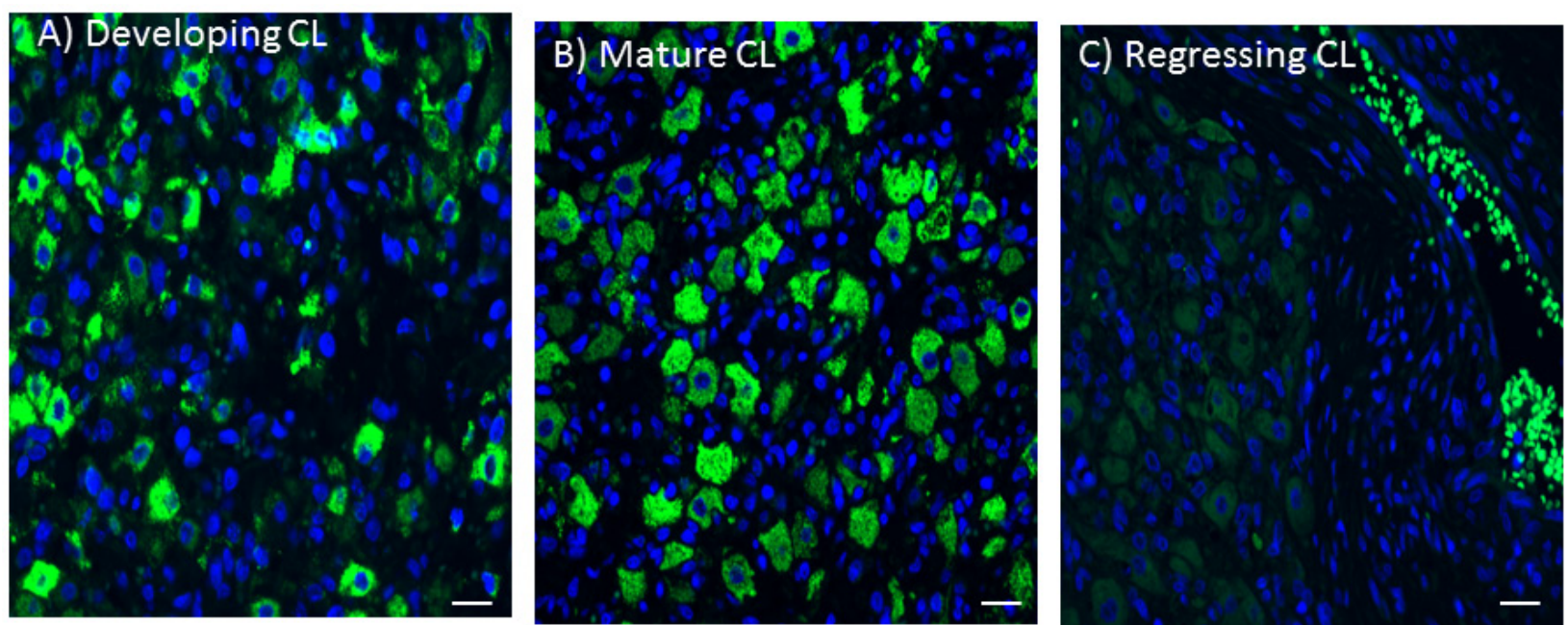

Figure 2. Representative images of immunofluorescence staining for StAR in developing CL (A) mature CL (B), regressing CL (C). Nuclei was stained with 4',6-diamidino-2-phenylindole dilactate (DAPI), scale bar represent 50 micrometer. 
The effect of the stage of the estrous cycle on TLR2 and TLR4 $\mathrm{mRNA}$ expression in the bovine CL

PCR amplified products for TLR2 and TLR4 were the predicted size (data not shown). Relative steady state levels of TLR2 and TLR4 mRNAs in CL samples taken during the different stages of the estrous cycle, including developing, mature, and regressed stages of the CL, are shown in Figures 3 and 4 . Expression of TLR2 and TLR4 mRNAs was detected in all stages of cyclic CLs. An upregulation of TLR2 mRNA was only detected in rCL (Fig. 3). The steady state level of TLR4 mRNA was higher in $\mathrm{mCL}$ and remained at high levels in $\mathrm{rCL}$, relative to dCL (Fig. 4).

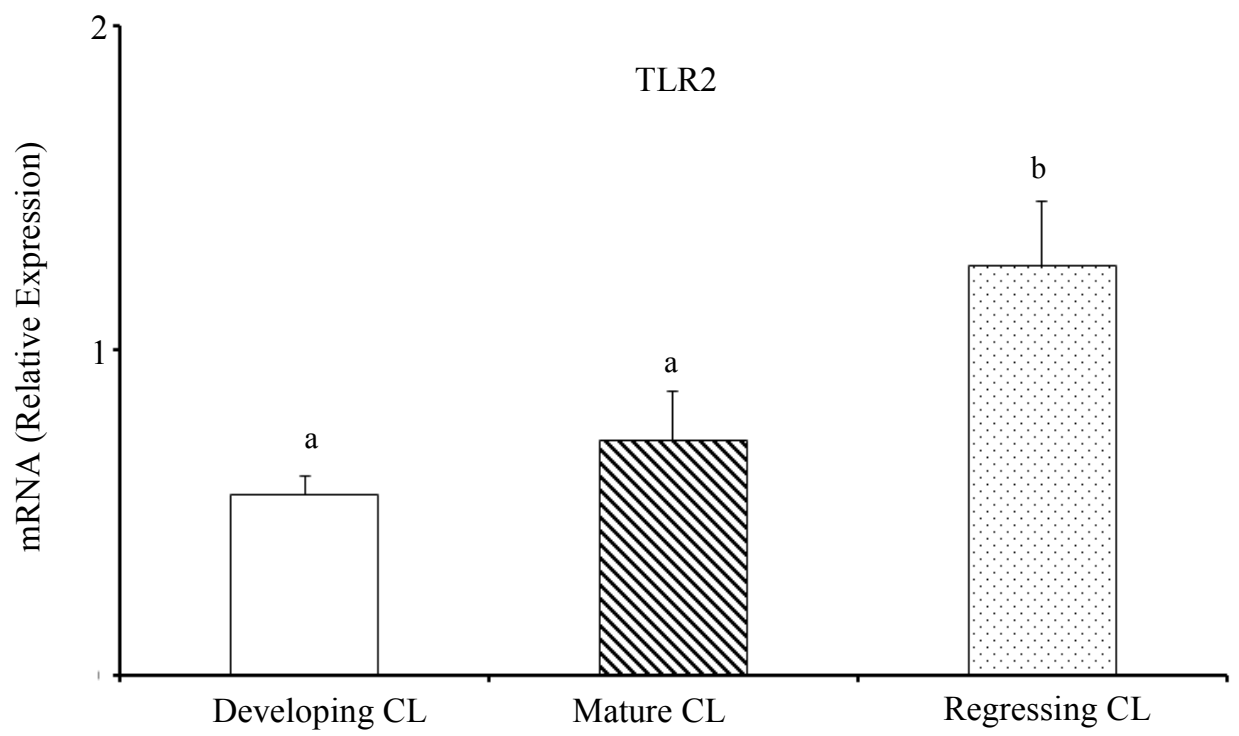

Figure 3. Relative expression of TLR2 mRNA (Mean \pm SEM) in the bovine CL during the different stages of the estrous cycle; developing CL (dCL; $\mathrm{n}=6$, approx. days 3-6), mature $\mathrm{CL}(\mathrm{mCL} ; \mathrm{n}=5$, approx. days 8-12), and regressing $\mathrm{CL}$ ( $\mathrm{rCL} ; \mathrm{n}=5$, approx. days 17-19) The different letter $(a, b)$ indicates differences $(\mathrm{P}<0.05)$ among groups.

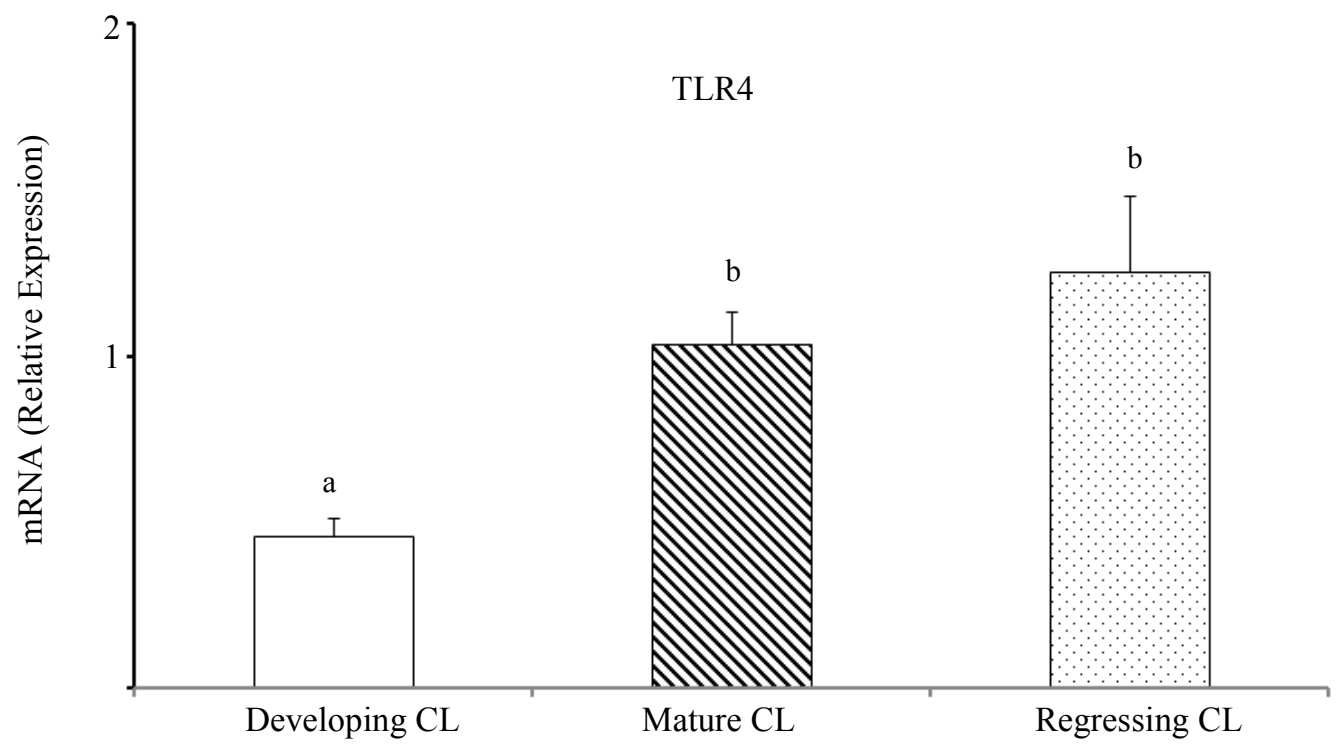

Figure 4. Relative expression of TLR4 mRNA (Mean \pm SEM) in the bovine CL during the different stages of the estrous cycle; developing CL (dCL; $\mathrm{n}=6$, approx. days 3-6), mature $\mathrm{CL}(\mathrm{mCL} ; \mathrm{n}=5$, approx. days 8-12), and regressing $\mathrm{CL}$ ( $\mathrm{rCL} ; \mathrm{n}=5$, approx. days 17-19) The different letter $(a, b)$ indicates differences $(\mathrm{P}<0.05)$ among group.

\section{Localization of TLR2 and TLR4 proteins in the bovine CL}

The presence of TLR2 protein in bovine CL is shown in Figure 5. Localization of TLR2 protein was apparent in both large and small luteal cells. When comparing the stages of the estrous cycle, a prominent immunofluorescent signal for the TLR2 protein was observed only in rCL. The presence of the TLR4 protein in bovine CL was clearly detected in luteal cells (Fig. 6) of both $\mathrm{mCL}$ and rCL but not dCL. 

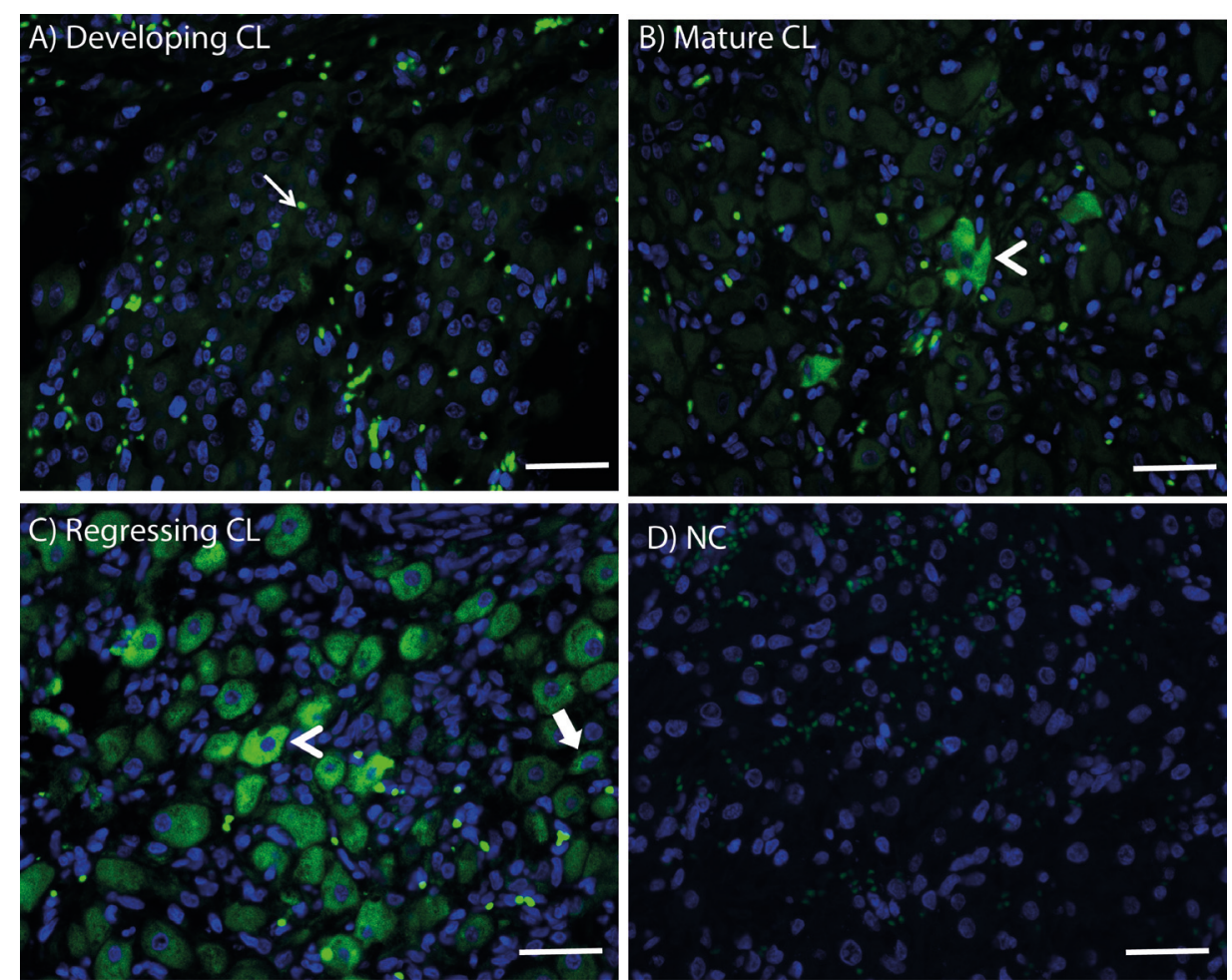

Figure 5. Representative images of immunofluorescence staining for TLR2 (Toll-like receptor 2) in developing CL (A) mature CL (B ), regressing CL (C) and Negative Control (NC, D). TLR2 proteins (FITC, $488 \mathrm{~nm}$ ) were localized in both large (white arrowhead) and small luteal (white large arrow) cells. Erythrocytes (white small arrow) in the CL were also appeared due to auto-fluorescence. Nuclei was stained with 4',6-diamidino-2-phenylindole dilactate (DAPI), scale bar represent 50 micrometer.
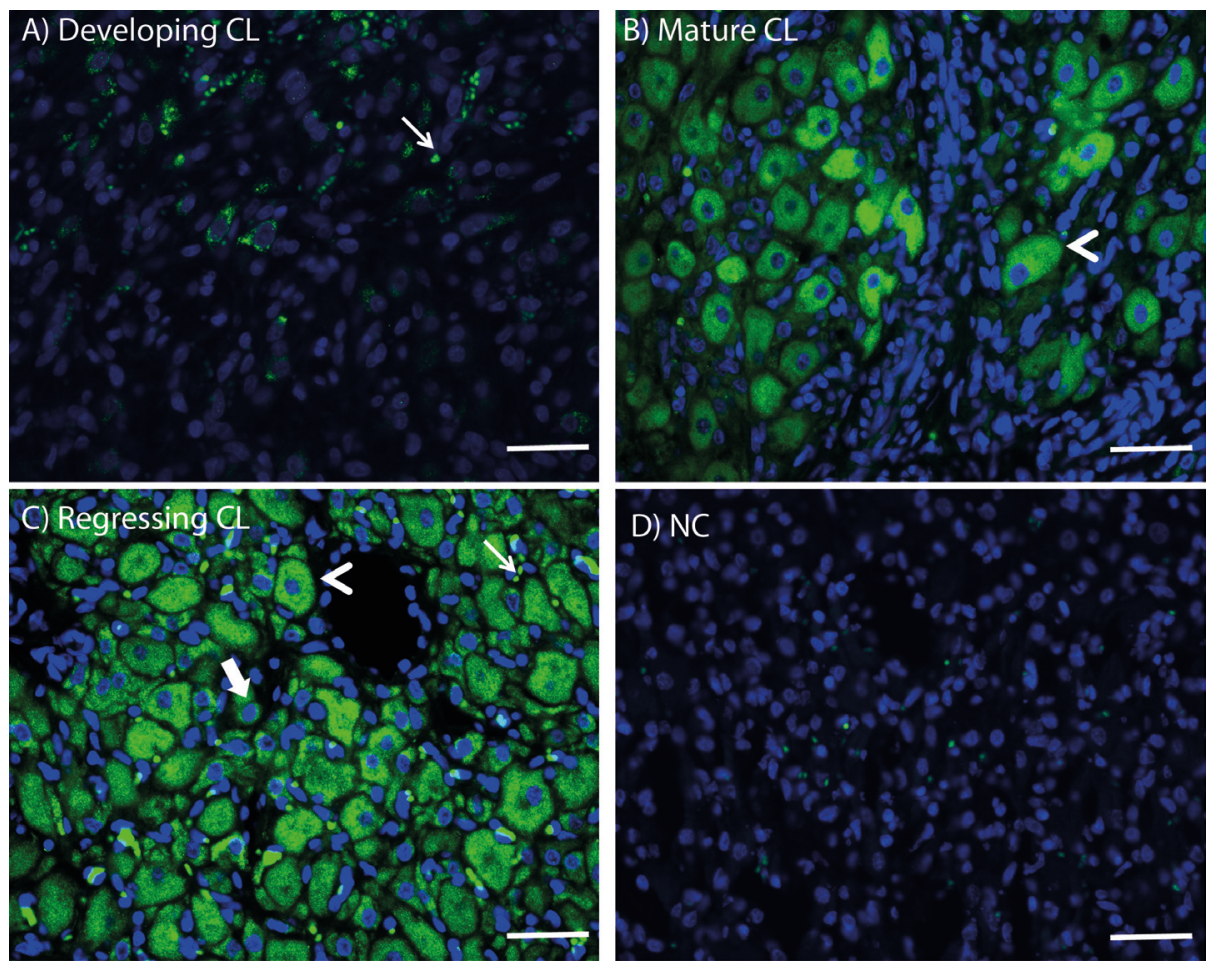

Figure 6. Representative images of immunofluorescence staining for TLR4 (Toll-like receptor 4) in developing CL (A,) mature CL (B ), regressing CL (C) and Negative Control (NC, D). TLR4 proteins (Dylight488, $488 \mathrm{~nm}$ ) were localized in both large (white arrowhead) and small luteal (white large arrow) cells. Erythrocytes (white small arrow) in the CL were also appeared due to auto-fluorescence. Nuclei was stained with 4',6-diamidino-2-phenylindole dilactate (DAPI), scale bar represent 50 micrometer. 


\section{Discussion}

The role of TLR in the reproductive tract has focused on the endometrium, and placental tissues under physiological and pathological conditions such as ovulation, fertilization, LPS challenges, endometritis, chorioamnionitis, and pre-eclampsia (AmJadi et al., 2014; Kannaki et al., 2011). The TLR-regulation of embryonic interferon- $\tau$ secretion was clearly shown in the ruminants (Ruiz-Gonzalez et al., 2015). Moreover, during early pregnancy, expression profiles of TLRs dramatically changed in both peripheral blood leukocytes (PBLs) and trophoblast cells of ewes (Kaya et al., 2017). The CL could be another potential tissue for TLR regulation since critical actors of the immune system play roles in the development and regression mechanisms of the CL. Expression profiles and cellular localization of TLR2 and TLR4 were detected in the bovine CL in the present study. Consistent with our results, two different research groups have also published their results which emphasized regulatory roles of TLR2 and TLR4 in the bovine CL during the estrous cycle (Gadsby et al., 2017; Lüttgenau et al., 2016). For example, Lüttgenau et al. (2016) indicated TLR 2 and 4 mRNA expressions were upregulated in the $\mathrm{CL}$ at mid-and late stages of the estrous cycle, compared with those collected during the developing stage of CL in the estrous cycle. Although Lüttgenau et al. (2016) did not show an increase in TLR2 and TLR4 mRNA on day 17 compared to mid stage of the cycle, we report an upregulation for TLR2 in regressing CL of the estrous cycle. A further increase in TLR2 on regression stage of CLs during the estrous cycle in bovine corpus luteum in the present study could be based on using later days CL (on day 17- 19) for our regression group. Similarly, Gadsby et al. (2017) have also indicated that an increased expression profiles of TLR2 and TLR4 at mRNA levels during the regression stage of the estrous cycle in bovine CL (days 18-20 of the estrous cycle) collected from the abattoir.

Earlier studies indicated that the luteolytic process was accompanied by changes in the levels of many endogenous molecules including ROS, endothelial-derived proteins, and lipophilic molecules in rCL (Pate et al., 2012; Skarzynski and Okuda 2010). It is also known that these endogenous molecules serve as ligands to induce TLR2 and TLR4 signaling (Piccinini and Midwood 2010; Kannaki et al., 2011). When the cell surface TLRs are bound with endogenous ligands triggering TLR signaling, MyD88 (myeloid differentiation primary response gene 88) -dependent or -independent pathways are activated in the cytoplasm (Fitzgerald et al., 2001). Both pathways stimulate the secretion of pro-inflammatory cytokines. Similarly, proinflammatory gene expression increases during regression of the CL (Atli et al., 2012; Shirasuna et al., 2012). Therefore, an increase in both TLR2 and TLR4 mRNA and protein levels in rCL in the present study may indicate roles of TLR signaling in the proinflammatory cytokine-mediated regressing mechanism in bovine CL. Similarly, this statement was also confirmed in bovine CL by Gadsby et al. (2017). They are indicated that one or more of the TLRs found within the CL may play a role in luteolysis, perhaps via proinflammatory cytokine mRNA expression.

In the present study, expression of TLR2 and TLR4 proteins was detected in luteal cells and may suggest that luteal cells, accompanied by other types of cells, induce the immune system for luteal regression. Similarly, Luttgenau et al. (2016) observed immunoreactivity for TLR 2 and 4 in both endothelial and luteal cells in bovine CL. Earlier studies suggest that CL physiology is closely associated with immune cells at certain stages of the estrous cycle. Specifically, during luteolysis, immune cell infiltration to the $\mathrm{CL}$ increases (Penny, 2000) and they are considered to play a role in luteolysis. Although these immune cells are not responsive to $\mathrm{PGF}_{2 \alpha}$ in $\mathrm{dCL}$, luteal cells respond to $\mathrm{PGF}_{2 \alpha}$ by increasing the expression of those genes that have regulatory functions on immune cells in $\mathrm{mCL}$ (Mondal et al., 2011). Therefore, the stimulation of TLR expression in luteal cells in $\mathrm{mCL}$ and $\mathrm{rCL}$ as observed in the present study may relate to an increased active immune status of the CL. As the immune cells and their signaling molecules have been linked to progesterone production and its regulation (Liptak et al., 2005; Mondal et al., 2011), the progesterone-producing luteal cells may undergo immune-cell like changes to cooperate in the mechanism of luteal maturation and regression.

Bovine CL, during the developing stages, does not respond to luteolytic $\mathrm{PGF}_{2 \alpha}$ injection (Mondal et al., 2011). One of the reasons for this non-responsiveness was proposed in a recent study (Sen et al., 2006) in which expression levels of PKC $\varepsilon$ were found to increase 10 -fold in $\mathrm{mCL}$ compared to dCL. Moreover, a specific PKC $\varepsilon$ inhibitor blocked the luteolytic response to $\mathrm{PGF}_{2 \alpha}$ in steroidogenic cells (Sen et al., 2006). Similar to PKC $\varepsilon$ expression in bovine CL, both TLR4 mRNA and protein levels increased in $\mathrm{mCL}$ and $\mathrm{rCL}$ compared to the developing stages in the present study. Since PKCE is a critical component of TLR4 signaling (McGettrick et al., 2006) and expression of both PKCe and TLR4 increased at the same stages of the CL, TLR4 is possibly a critical component for the $\mathrm{PGF}_{2 \alpha}$ response in the CL, implying a potential role of TLR4 in the acquisition of luteolytic capacity. Similarly, immune related genes increased only after $\mathrm{PGF}_{2 \alpha}$ induction in mCL compared to dCL (Mondal et al., 2011). Moreover, enhanced populations of specific types of immune cells and cell-to-cell communication between immune and the other types of CL cells in the mature stage clearly indicate immune regulation of the luteolytic pathway (Poole and Pate 2012; Penny 2000).

As a conclusion, the expression levels and cellular localization of TLR2 and TLR4 in bovine CL at different stages of the estrous cycle were described in the present study. Consistent with recently published studies investigating TLR2 and 4 in the bovine CLs (Gadsby et al., 2017; Lüttgenau et al., 2016), our data suggest the possible involvement of these TLRs and a related pathway in luteal cells during the regression period of bovine $\mathrm{CL}$ as indicated by increased expression levels of TLR2 and TLR4. 


\section{Acknowledgements}

This study was supported by Dicle University Scientific Research Foundation (DUBAP) (12-VF-60 to Mehmet O. Atli).

\section{References}

Akira S. 2003. Toll-like receptor signaling. J Biol Chem, 278:38105-38108.

Amjadi F, Salehi E, Mehdizadeh M, Aflatoonian R. 2014. Role of the innate immunity in female reproductive tract. Adv Biomed Res, 3:1.

Arosh JA, Parent J, Chapdelaine P, Sirois J, Fortier MA. 2002. Expression of cyclooxygenases 1 and 2 and prostaglandin E synthase in bovine endometrial tissue during the estrous cycle. Biol Reprod, 67:161-169.

Atli MO, Mehta V, Baruah KK, Bender RW, Bastos MR, Guenther JN, Luo W, Vezina CM, Wiltbank MC. 2011. Induction and localization of five immediate early genes (IEGs) in the bovine corpus luteum (CL) at 30 min after prostaglandin F2 alpha (PGF) treatment. Reprod Dom Anim, 46:(supp1)87-87.

Atli MO, Bender RW, Mehta V, Bastos MR, Luo W, Vezina CM, Wiltbank MC. 2012. Patterns of gene expression in the bovine corpus luteum following repeated intrauterine infusions of low doses of prostaglandin F2alpha. Biol Reprod, 86:130.

Davies D, Meade KG, Herath S, Eckersall PD, Gonzalez D, White JO, Conlan RS, O'Farrelly C, Sheldon IM. 2008. Toll-like receptor and antimicrobial peptide expression in the bovine endometrium. Reprod Biol Endocrinol, 18:6:53.

Fitzgerald KA, Palsson-McDermott EM, Bowie AG, Jefferies CA, Mansell AS, Brady G, Brint E, Dunne A, Gray P, Harte MT, McMurray D, Smith DE, Sims JE, Bird TA, O'Neill LA. 2001. Mal (MyD88-adapterlike) is required for Toll-like receptor-4 signal transduction. Nature, 413:78-83.

Gadsby JE, Tyson Nipper AM, Faircloth HA, D'Annibale-Tolhurst M, Chang J, Farin PW, Sheldon IM, Poole DH. 2017,. Toll-like receptor and related cytokine mRNA expression in bovine corpora lutea during the oestrous cycle and pregnancy. Reprod Domest Anim, 52:495-504.

Horne AW, Stock SJ, King AE. 2008. Innate immunity and disorders of the female reproductive tract. Reproduction, 135:739-749.

Kannaki TR, Shanmugam M, Verma PC. 2011. Tolllike receptors and their role in animal reproduction. Anim Reprod Sci, 125:1-12.

Kaya MS, Kose M, Guzeloglu A, Kiyma Z, Atli MO. 2017. Early pregnancy-related changes in toll-like receptor expression in ovine trophoblasts and peripheral blood leukocytes. Theriogenology, 93:40-45.

Koga K, Mor G. 2008.Expression and function of tolllike receptors at the maternal-fetal interface. Reprod $\mathrm{Sci}$, 15:231-242.

Liptak AR, Sullivan BT, Henkes LE, Wijayagunawardane MP, Miyamoto A, Davis JS, Rueda BR, Townson DH. 2005. Cooperative expression of monocyte chemoattractant protein 1 within the bovine corpus luteum: evidence of immune cell-endothelial cell interactions in a coculture system. Biol Reprod, 72:1169-1176.

Livak KJ, Schmittgen TD. 2001. Analysis of relative gene expression data using real-time quantitative PCR and the 2(-Delta Delta C(T)) method. Methods, 25:402408.

Lüttgenau J, Herzog K, Strüve K, Latter S, Boos A, Bruckmaier RM, Bollwein H, Kowalewski MP. 2016. LPS-mediated effects and spatio-temporal expression of TLR2 and TLR4 in the bovine corpus luteum. Reproduction, 151:391-399.

Mamluk R, Chen D, Greber Y, Davis JS, Meidan R. 1998. Characterization of messenger ribonucleic acid expression for prostaglandin F2 alpha and luteinizing hormone receptors in various bovine luteal cell types. Biol Reprod, 58:849-856.

McGettrick AF, Brint EK, Palsson-McDermott EM, Rowe DC, Golenbock DT, Gay NJ, Fitzgerald KA, O'Neill LA. 2006. Trif-related adapter molecule is phosphorylated by PKC\{epsilon\} during Toll-like receptor 4 signaling. Proc Natl Acad Sci, 103:91969201.

Mondal M, Schilling B, Folger J, Steibel JP, Buchnick H, Zalman Y, Ireland JJ, Meidan R, Smith GW. 2011. Deciphering the luteal transcriptome: potential mechanisms mediating stage-specific luteolytic response of the corpus luteum to prostaglandin F(2)alpha. Physiol Genomics, 43:447456.

Pate JL, Johnson-Larson CJ, Ottobre JS. 2012. Life or death decisions in the corpus luteum. Reprod Domest Anim, 47:297-303.

Pate JL, Landis Keyes P. 2001. Immune cells in the corpus luteum: friends or foes? Reproduction, 122:665676.

Penny LA. 2000. Monocyte chemoattractant protein 1 in luteolysis. Rev Reprod, 5:63-66.

Piccinini AM, Midwood KS. 2010 DAMPening Inflammation by modulating TLR signaling. Mediators of Inflammation, Article ID 672395, doi:10.1155/2010/672395.

Poole DH, Pate JL. 2012. Luteal microenvironment directs resident $\mathrm{T}$ lymphocyte function in cows. Biol Reprod, 86:1-10.

Ruiz-Gonzalez I, Xu J, Wang XQ, Burghardt RC, Dunlap KA, Bazer FW. 2015. Exosomes, endogenous retroviruses and toll-like receptors: pregnancy recognition in ewes. Reproduction, 149:281-91.

Sen A, Wright M, Inskeep EK, Flores JA. 2006. Participation of specific PKC isozymes in the inhibitory effect of ET-1 on progesterone accumulation in cells isolated from early- and mid-phase corpora lutea. Domest Anim Endocrinol, 31:284-299.

Shirasuna K, Jiemtaweeboon S, Raddatz S, Nitta A, Schuberth HJ, Bollwein H, Shimizu T, Miyamoto A. 2012. Rapid accumulation of polymorphonuclear neutrophils in the corpus luteum during prostaglandin F(2alpha)-induced luteolysis in the cow. PloS ONE, 7: e29054.

Silva E, Leitao S, Henriques S, Kowalewski MP, Hoffmann B, Ferreira-Dias G, da Costa LL, Mateus 
L. 2010. Gene transcription of TLR2, TLR4, LPS ligands and prostaglandin synthesis enzymes are upregulated in canine uteri with cystic endometrial hyperplasia-pyometra complex. $J$ Reprod Immunol, 84:66-74.

Skarzynski DJ, Okuda K. 2010. Inter- and intra- cellular mechanisms of prostaglandin $\mathrm{F}$ (2 alpha) action during corpus luteum regression in cattle. Soc Reprod Fertil, 67:305-324.

Wiltbank MC. 1994. Cell-types and hormonal mechanisms associated with mid-cycle corpus-luteum function. J Anim Sci, 72(7):1873-1883. 